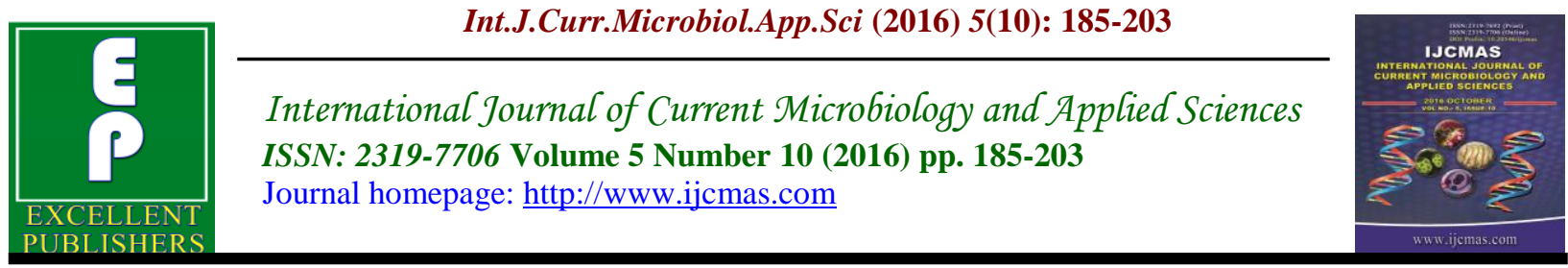

Original Research Article

http://dx.doi.org/10.20546/ijcmas.2016.510.021

\title{
Effect of Some Fruits, Vegetables and Legumes on the Immunity of Diabetic Rats
}

\author{
Hala Mohamed Ali Wahba* \\ Home Economics Department, Specific Education Faculty, Minufiya University, Egypt \\ *Corresponding author
}

Keywords

Immunity, liver enzymes, internal organs, rats, diabetes mellitus, lipid profile.

Article Info

Accepted:

12 September 2016 Available Online: 10 October 2016
A B S T R A C T

The use of traditional plant for diabetes mellitus is widely practiced in Middle East countries. The aim of this investigation is to evaluate the biological effect of fruits, vegetables and legumes on lowering the level of glucose in blood and enhancement of the immune system. Thirty-two male albino rats $(130-200 \mathrm{~g})$ each were used in the study, 28 of rats diabetes by single intraperitoneal injection of alloxan at dose level of $150 \mathrm{mg} / \mathrm{kg}$ body weight. All rats (normal and diabetic) were kept on casein basal diet for 4 weeks. They were then divided into 5 groups. At the end of experiment the weight gain was calculated. Organs (liver - heart - kidney - spleen - lungs) of each rat were removed rapidly and were weighted separately. Blood samples were used for estimation of fasting serum glucose, serum GPT and GOT, serum lipid profile, kidney function, cellular and humoral immunity. Data showed that serum GOT and GPT levels declined significantly $(\mathrm{p}<0.01)$ in all treated groups that fed on $20 \%$ powder and extract when compared with diabetic control positive, while feeding rat on basal diet containing $20 \%$ vegetables extract, legumes powder and fruits extract revealed more hypoglycemic effect. The best results for immunity were $20 \%$ fruits extract and vegetables group.

\section{Introduction}

Diabetes mellitus is a group of diseases characterized by a defect in insulin secretion and increased cellular resistance to insulin, resulting in elevated plasma glucose levels, abnormalities carbohydrate and lipid metabolism, characteristic pathologic changes in the nerves and small blood vessels, and aggravation of atherosclerosis (Lee and Nieman, 2003). Since 1932, diabetes mellitus has been among the top 10 leading causes of death in America.
It is a major cause of blindness, renal failure, congenital malformation, and lower extremity amputation. The prevalence of coronary artery disease and peripheral vascular disease is twice as common among persons with diabetes, as compared with those without diabetes (American Diabetes Association, 2014).

In 1997, an estimated 124 million people worldwide had diabetes, $97 \%$ of these 
having type 2 diabetes, otherwise known as non- insulin -dependent diabetes mellitus (NIDDM) or adult - onset diabetes - type 2 diabetes is most prevalent in the adult population, afflicting approximately $17 \%$ of people aged greater than 65years (Winlers, 2006). Obesity is a strong predisposing factor for type 2 diabetes. Berry polyphenols may help prevent obesity by inhibiting digestive enzymes, such as lipase, thereby lowering fat absorption (McDougall, Kulkarni, and Stewart, 2008). Hypoglycemic effect of bilberry is a desirable effect for helping to prevent or control type 2 diabetes, which is a highly prevalent condition caused by insulin resistance and $B$ cell failure (ADA, 2010). Type 2 diabetes is associated with increased oxidative stress, inflammation, and dyslipidemia, and is accompanied by an increased risk of CVD, cancer, and vision loss through cataract and retinopathy (Choi et al., 2008; ADA, 2010).

The use of traditional plant for diabetes mellitus is widely practiced in Middle East countries. The world health organization (WHO) has recommended that this should be encouraged, especially in countries where access to the conventional treatment of diabetes is not adequate (WHO, 1980). The berry has various other reputed health benefits, although most interest has been focused on anthocyanin-related antioxidant effects (Park et al., 2007). There are many studies that have investigated the antioxidant and other health-related effects of anthocyanin -rich berries and extracts or juices. bilberry extract protected cells against oxidative damage., bilberry or anthocyanin extracts of bilberry protects rat liver microsomes against oxidative damage and apolipoprotein B against ultraviolet (UV)-induced oxidative fragmentation (Valentova et al., 2006). The bilberry plant is reputed to possess antidiabetic properties, and its berries and leaves (as well as those of other Vaccinium species) have been used for centuries to ameliorate the symptoms of diabetes.grape seed extracts were effective in increasing CAT and GPx activation in the liver tissue, but not so effective in controlling the formation of lipid peroxides within the liver tissue (Cravotto et al., 2010).

A number of herbal products are known to facilitate enhancement of the immune system. These include Echinacea, garlic, cats claw, astragolus, licorice and other herbs. Flavonoid - rich and carotenoid - rich herbs may be expected to enhance the immune system (Tyler, 1994).

\section{Materials and Methods}

Studied ingredients were prepared prior to inclusion in diets as follows:

Fruits, Vegetables and Legumes were cleaned, sun- dried under vacuum at low temperature) and milled to fine powder then added at $20 \%$ level to diets.

\section{Preparation of plant extracts}

The clean fruits, vegetables and legumes were ground using porcelain grinder to pass through sievemesh pores of $1 \mathrm{~mm}$ diameter and used as powdered dried plants.

Sample $(200 \mathrm{~g})$ of fruits $+1000 \mathrm{ml}$ distilled water, $200 \mathrm{~g}$ sample of

vegetables $+1000 \mathrm{ml}$ distilled water, $200 \mathrm{~g}$ sample of legumes +

condensers then boiled for one hour to obtain the extracts.

The boiled mixture was coded and filtered.

The filterate poured in different petri dishes and dried under vacuum at $70^{\circ} \mathrm{c}$ to dried 
powder. The powder has been dissolved in certain amount of distilled water. The amount of solution equivalent to $20 \%$ dried was administered orally using a tube.

\section{Biological investigation}

Animals: Thirty-two (32) Sprague - Dawley male albino rats weighting $130-200 \mathrm{~g}$ each, were used in this study. All rats were fed the control (casein) diet for4 consecutive days. Each rat was housed in an individual stainless steel cage under controlled condition. Diets were introduced to rats in a special non- scattering feeding cup to avoid loss of food and contamination. Tap water was provided to rats by mean of glass tubes projecting through wire cages from inverted bottles supported to one side of the cage.

\section{Induction of diabetes in rats}

Alloxan: Pure chemical fine (BDH, obtained from Sigma) was used for inducing diabetes in this study. Untreated rats are referred to as the control negative (control-group), while alloxan treated rats are the control positive (control + group); these are groups 1 and 2 respectively. Diabetes was induced in normal healthy male albino rats via intraperitoneal injection of alloxan $150 \mathrm{mg} / \mathrm{kg}$ body weight according to the method described by Desai and Bhide, (1985). Six hours after the injection of alloxan, fasting blood samples were obtained by retro-orbital method to estimate fasting serum glucose. Rats having fasting serum glucose more than $200 \mathrm{mg} / \mathrm{dLwere}$ considered diabetics NDDG, (1994).

\section{Diets}

Basal diet was prepared according to Reeves et al., (1993). It consists of $20 \%$ protein, 10 $\%$ sucrose, $4.7 \%$ corn oil, $2 \%$ choline chloride, $1 \%$ vitamin mixture, $3.5 \%$ salt mixture and $5 \%$ fibers. The remainder was corn starch up to $100 \%$.

\section{Experimental diets}

Experimental diet was prepared from basal diet plus the powdered fruits $(20 \%)$, fruits extract $(20 \%)$, powdered vegetables $(20 \%)$, vegetables extract $(20 \%)$, powdered legumes $(20 \%)$, legumes extract $(20 \%)$.

\section{Experimental design}

The experimental work was done in the Faculty of Science, AL-baha university. Rats were housed in wire cages in room maintained at $25 \pm 2^{\circ} \mathrm{C}$ and kept under normal healthy conditions. All were fed on normal basal diet for one week before starting the experiment for acclimatization. After one - week period, the rats were divided into groups each with similar alive body weight and were housed individually in wire cages.

\section{Rat groups}

Group 1: Control group (control negative) 4 rats (normal rats) - in which rats were fed normal - basal diet for 45 days.

Group 2: Control positive group (control +) 4 rats. In which rats were fed normal - basal diet for 45 days. These rats were randomly chosen after injection with alloxan by six hours.

Group 3: Fruits groups (8 hyperglycemic rats) were fed on basal diet containing dried fruits which were:

Grapes (Vitis vinifera), Strawberry (Frogaria chiloensis), Mulberry (Morus alba, L.),Apple (Malus pumila),

This group was furtherly subdivided into 2 subgroups: 
Group 3a: Powdered fruits -4 control + rats: In which rats were fed $20 \%$ powder fruits diet for 45 consecutive days.

Group 3b: Fruits extract -4 control +4 rats: In which rats were fed normal - basal diet with fruits extract $20 \%$ for 45 days.

Group 4: Vegetables group (8 hyperglycemic rats) were fed on basal diet containing vegetables which were:

Cauliflower (Brassica oleracea var. botrytis), Onion (Allium cepa, L.), Garlic (Allium sativum, L.), Mushroom

This group was furtherly subdivided into 2 sub groups:

Group 4a: Powdered vegetables - 4 rats: In which rats were fed $20 \%$ powdered vegetables diet for 45 consecutive days.

Group 4b: Vegetables extract - 4 rats: In which rats were fed normal -basal diet mixed with vegetables extract $20 \%$ for 45 days.

Group 5: Legumes group (8 hyperglycemic rats) were fed on basal diet containing legumes which were:

Soybeans (Glycine max, L. Merrill), Chickpea (Cicer arietinum),

Fenugreek (Trigonella foenum graecum, L.) sedds, Barley (Hordeum rulgare, L.).

This group was furtherly subdivided into 2 subgroups:

Group 5a: Powdered legumes - 4 rats: In which rats were fed $20 \%$ powdered legumes diet for 45 consecutive days.

Group 5b: Legumes extract -4 rats: In which rats were fed normal -basal diet with $20 \%$ legumes extract for 45 days.

\section{Blood sampling}

From all the previously mentioned groups, blood samples were collected after 12 hour fasting at the end of the experiment. Using the retro - orbital method by means of a microcapillary glass heparinized tubes, blood was collected into a dry clean centrifuge tube and left to clot in a water bath (37c)at room temperature for half an hour. The blood was centerifuged for 10 minutes at 3000 r.p.m. to separate the serum.

Serum was carefully aspirated and transferred into clean quit fit plastic tubes and kept frozen at (20c) until the time of analysis. The organs (liver, kidney, heart, lungs and spleen)were removed and washed in saline solution, weighted and kept in formalin solution $(10 \%, \mathrm{v} / \mathrm{v})$ according to methods described by Drury and Wallington (1980), dried then weighted and relative weight of organs was calculated.

\section{Biological Evaluation}

Relative weight $=\frac{\text { Organ weight }}{\text { Animal body weight }} \times 100$

All rats were weighted once weekly. At the end of the experiment, biological evaluation of the different diets was carried out by determination of body weight gain \% (BWG $\%$ ), food efficiency ratio (FER) according to Chapman et al., (1959). Using the following formula

\section{Biochemical analysis}

Immunity study: Assessment of both cellular and humoral immunity efficiency was carried out in the Faculty of Science AL-Baha University. Total serum proteins were determined by using biuret reaction according to Weichselbaum (1946). 
Quantitative estimation of fractions of serum proteins: according to the technique described by Laemmli (1970). Cellular immune response: Separation of lymphocytes: (Boyum, 1968 and Burrels and Wells (1977). Total lymphocyte count (Hudson and Hay, 1980).According to viability cell count (Rai-El-Balahaa et al., 1985; Denise et al., 1992). Phagocytosis according to (Woldehiwet and Rowan, 1990).

Determination of blood glucose: carried out Tietz (1976) and Yound (1975). triglycerides was carried out according to Jacobs and Van Denmark (1960). HDL according to the method of Fnedewaid (1972) and Gordon and Amer (1977). Determination of VLDL and LDL carried out according to the method of Lee and Nieman (1996). Determination of (GOT) was carried out according to the method of Henry (1974) and Yound (1975). Creatinine: concentration according to Larsen, (1972).Uric acid: was according to Carawy, (1955).Urea: was according to Fawcette and Scott (1960).

\section{Statistical Analysis}

Statistical analysis were performed by using computer program statistical package for social science (SPSS), and compared with each other using the suitable tests. All obtained results were tabulated. Statistical analysis has been achieved using IMB-P-C computer by SPSS, program (SPSS, 1998).

\section{Result and Discussion}

Food intake (FI), body weight gain (BWG) and food efficiency ratio (FER).

Data of table (1) show FI, BWG \% and FER of hyperglycemic rats as affected by feeding on fruits, vegetables and legumes diets. It could be observed tables (1) that due to hyperglycemia loss of weight occurred and negative value of BWG was recorded; BWG $\%$ for control (+) group was $-12.73 \%$ this was not due to loss of appetite (FI increase /from (16.9 to $17.1 \mathrm{~g} /$ day), but was possibly due to physiological disorders causing lower food efficiency ratio which decreased from 0.055 to -0.400 and lower protein efficiency ratio which declined from 0.458 to -0.332 . Similar trends were reported by Ahmed, Reham (2007) which found that diabetic rats showed negative values of FER (.040) and BWG \% (-12.69 \%); food intake was decreased from 13.99 to $17.1 \mathrm{~g} /$ day. Also our findings agree with those of Stoev et al., (2000), who found that statistically significant decrease of the body weight for control positive group and increased organs weight. Rats fed on fruits, vegetables and legumes (table 1) showed no more negative values for FER, PER, or BWG \% indicating that all plant materials used corrected the mentioned changes; but to different levels. Sometimes the improvement in (PER, FER, BWG \%) so pronounced that values were ever better than that of the control (-) group. It could be noticed (table 1) that best PER, FER, and BWG \% among fruits, vegetables and legumes groups were nearly the same which recorded for legumes extract diet, while lowest improvement was found for fruits powder diet; other diets revealed intermediate improvement (vegetables extract \& powder, legumes powder, fruits extract). But this arrangement holds true for PER, FER or BWG \%.

\section{Weight of internal organs}

Data of tables (2) show the weight of internal organs of hyperglycemic rats as effected by feeding of fruits, vegetables and legumes.

It could be noted that due to hyperglycemic the weight of heart, kidneys and spleen increased, while that of liver and lungs 
decreased. These changes were corrected at different degrees when feeding on tested plant parts. Meanwhile all differences between values were non significant. Nevertheless, treatments could be arranged descendingly (the best is first) as follows; Liver: Legumes extract, legumes powder, fruits powder, fruits extract, vegetables extract and vegetables powder; Heart: vegetables powder, fruits powder, fruits extract, vegetables extract, legumes extract and legumes powder; Kidneys: vegetables powder, fruits powder, fruits extract, legumes powder and legumes extract; Spleen: Fruits extract, vegetables powder, vegetables extract, fruits powder, legumes extract and legumes powder; Lungs: legumes powder, legumes extract, This was found by Abo- Shadie (2002) when feeding hyperglycemic rats on $2 \%$ garlic diet, and were rat with accordance with El-Sayed (2001) who found a significant increase in liver weight of rats fed diet containing 5\% $P$. oleracear leaves, being possibly due to changes in liver content of liver.

\section{Biochemical parameters}

\section{Serum glucose}

Data presented in table (3) show the serum glucose level of diabetic rat when feeding on fruits, vegetables and legumes: It was revealed that alloxan induced diabetes raised the serum glucose, percent increase was about $78 \%$. This high serum glucose level was recorded even after 28 days of trial diabetic rats on normal basal diet without alloxan injection during the feeding experiment. Certain correction occurred on feeding with test plants. Chemoprevention involves the use of natural substances to reduce the risk of developing DM and its sequels (Ronald, 2001). The results of table (3) indicated that serum glucose for vegetables extract lower than all groups when compared with control positive significantly $(\mathrm{p}<0.01)$. Mentioned results in present study that fruits group, vegetables group and legumes group or their extract lower blood glucose level in diabetic rats when they were supplemented to the diet at levels $20 \%$ powdered and extract. The results of table (3) showed that serum glucose was less in the extract than the powder for vegetable and fruit groups, while for legumes serum glucose was lower for the powder. Moreover, Dietary fiber, in particular the soluble fiber fraction plays the important role in controlling glucose concentration in serum and other risk factors associated with diabetes (Giacco et al., 2002).The results are in agreement with Fatani et al., (2005) they found that oral administration of 50 and $100 \mathrm{mg} / \mathrm{kg}$ body weight of red grape seed proanthocyanidins for $72 \mathrm{~h}$ significantly increased pancreatic glutathione levels and inhibited the increase in lipid peroxidation caused by alloxan $(\mathrm{p}<0.001)$. On the other hand, a significant reduction in pancreatic total nitrate content $(p<0.001)$ was observed. Furthermore, GSP caused significant decline in the hyperglycemia induced by alloxan $(\mathrm{p}<0.001)$. Also, this is result are agreement with Arola et al., (2004). It should be noted that the present work was designed mainly to raise the immunity of diabetics, which are usually subjected to serious disorders other than the diabetes mellitus. The suggested diets, however, revealed pronounced serum glucose lowering effect.

\section{Lipids fractions}

Data presented in tables (4) show the level of serum lipids fractions (TC, TG, HDL, LDL, vLDL) and calculated atherogenic index (AF) of hyperglycemic rats. It could be noticed (Tables 4) that along with the increase of serum glucose (Tables 3) in diabetic rats, fasting serum TC, TG, LDL \& VLDL were increased, while the level of HDL decreased. This is a usual disorder 
recorded for hyperglycemia (Mohamed, Manal, 2006). Nevertheless, the reverse was found when feeding rats on selected fruits, vegetables and legumes. Similar trends were reported by El-Sayed, Mona (2005); Saad, Gehan (2006); Ahmed, Reham (2007); ElMalah, Maysa (2007) and Gadall, Sanaa (2007) working on fruits, legumes, vegetables and herbs. Moreover, El-Adawi (1997) found that the concentration of plasma cholesterol, triglycerides, fatty acids and phospholipids are increased in diabetes mellitus. Diabetic rats exhibited high triglycerides and phospholipids compared to normal rats.

Insulin also affect fat metabolism. Lack of insulin causes extreme atherosclerosis, often leading to heart attack. It causes also a great increase in the amount of stored triglycerides in the liver, leading to a very fatty liver. The reason is the following: the excess of free fatty acids in the blood causes a rapid diffusion of fatty acids into the liver cells (Lee and Niemen, 2003). It could be noticed (Tables 4) that best treatment, which showed lowest TC, TG, LDL and highest HDL were the collection of vegetables powder \& fruits extract groups, followed by the collection of legumes powder, vegetables extract and legumes extract groups then came the fruits powder group.

This was also found for the calculated A.I. The present results are confirmed by the findings of Ali et al., (2006) they found that raw garlic had a profound effect in reducing the glucose, cholesterol and triglyceride levels. Therefore because hyperlipidemeia is a major etiopathological factor for atherosclerosis, garlic may play an important role in the prevention of atherosclerosis. Our findings agreement with Sauls et al., (2006) they found that red wines and grape decrease lipid profile and saturated fatty acids. Fruits vegetable and legumes as well as powders of vegetables and legumes decreased the LDL levels than that recorded for the control (-) group.

Effect of fruits, vegetables, legumes and herbs groups on the liver function of diabetic rats

Data of tables (5) show the activities of GPT (AST) and GOT (AST) enzymes as influenced by feeding on fruits, vegetables and legumes diets (powders and extracts). It is evident (Table 5) that the activities of GPT and GOT could be nearly arranged the same and ascendingly as follows: Vegetables extract, fruit extract, legumes powder, fruit powder, vegetables powder and legumes extract. Such data indicated that the increase of enzymes activities due to hyperglycemia was corrected by feeding with botanical materials. Some diets (fruits powder) decreased the GPT activity exactly to the level recorded for the control (-) rats $(26 \mathrm{u} / \mathrm{L})$, this was also found for GOT in case of legumes powder diet $(62.3 \mathrm{u} / \mathrm{L})$.

Some other diets reduced the GPT (fruits extract, vegetables extract and legume powder) and the GOT (vegetables extract) activities to a level which was less than that recorded for the control (-) group. Eidi et al., (2006) they found that garlic extract significantly decreased serum glucose, total cholesterol, triglycerides, urea, uric acid, creatinine, GPT, GOT levels.Our findings agreement with Kim et al., (2002) they found that leaf (Brassica juncea) reduced serum glucose lipid peroxidation, liver and kidney associated with diabetes mellitus. Also, these results agreed with that of Ghamry (2004). The present result agreed also with those that of Nada et al., (1997).

Effect of fruits, vegetables and legumes diets groups on the kidneys function of diabetic rats

Diabetic nephropathy is a major 
complication of both insulin - dependent and non insulin - dependent diabetes mellitus, as reported by Velasquez et al., (1995), they suggested that hyperglycemia in diabetes is a critical factor in the development of the renal disease. Non protein nitrogen of the blood includes urea, uric acid and creatinine. They are usually of greater clinical interest (Contarow and Schepartz, 1967). Hyperglycemia, thereby caused the disorder of kidneys function as indicated by the increase of serum creatinine, were and uric acid levels (Tables 6). This confirmed the results obtained by others (El-Sayed, 2001; Mohamed, 2006 and Ahmed, 2007).

All botanical material used in present study corrected the disorders of kidneys function to different degrees as compared with control (+) group. In case of urea, however, none of diet reduced the level than that recorded for control (-) rats. On the other hand the control (-) groups which were: Creatinine (vegetables powder \& legumes extract), Uric acid (fruits extract, vegetable extract and legumes extract).

Botanical materials of table (6) could be arranged descendingly according to their beneficial effect on kidneys function as follows: Fruit extract, vegetable extract, legume extract and vegetable powder groups.

It is work mentioning that although lowest correction was found for fruit powder in case of creatinine (from 1.50 in control $(+)$ to $1.33 \mathrm{mg} / \mathrm{dl}$ ) \& urea (from 50 in control (+) to $44.67 \mathrm{mg} / \mathrm{dl}$ ) and in case of uric acid (from 2.77 in control (+) to $2.28 \mathrm{mg} / \mathrm{dl}$ ) percent decreases were $11.11 \& 4 \%$ which indicates the improvement of health status and kidneys function within 45 days of feeding. Possibly feeding for more period of time may cause much greater improvement.

\section{Immunity Parameters Cellular immunity}

Data of tables (7) show the cellular immunity (phagocytes and lymphocytes) of rats as affected by feeding on fruits, vegetables and legumes diets. Differences between control (-) and control (+) groups as well as by all treatments were insignificant. Nevertheless cellular immunity (Tables 7) could be arranged descendingly based on absolute values (regardless of statistics) of phagocytes as follows: vegetables powder, vegetables extract, fruit extract, fruit powder, legumes powder \& legumes extract and according to lymphocytes: Vegetables extract, fruit powder, legumes powder, vegetables powder, fruits extract and legumes extract. Best diet seems to be vegetables extract and the lowest effecting was legumes extract.

Meanwhile compared to control (+) group, least effecting diet (legumes extract) showed about $50 \%(49.45 \%)$ improvement in cellular immunity (based on lymphocytes); Based on phagocytes this diet showed 7.14 $\%$ improvement. Changes of lymphocytes was considerably greater in case of vegetables powder diet, showing about $64 \%$ improvement comparing to control (+) group (Table 8).

Thiery et al., (2006) found that garlic (Allium sativum) extract inhibited the adhesion of monocytes to IL -1 alpha stimulated endothelial cells. Garlic preparation have also been reported the immune system of patients with AIDS (Abdullah et al., 1989).

\section{Humoral immunity}

\section{Alpha, beta and gamma globulins}

Data of tables (9) show the levels of 
humoral immunity as indicated by determining serum alpha, beta and gamma globulins. It is known that the more the level of globulins, the more immunity will be. For all fractions hyperglycemia resulted in the decrease of values (Tables 9) while the reverse was recorded when the rats showed some recovery which lowered the serum glucose (Table 9). Our findings agree with those of Winlers et al., (2006), they found that Allium sativum and Echinacea purpurea modulate the secretion of multiple cytokines. Lee et al., (2006) indicated that black berry, black raspberry, blue berry, strawberry extract inhibit growth and stimulate apoptosis of human cancer cells in vitro. Matos et al., (2006) found that strawberry contains IgE binding profilim and LTP which lower allergy. Stoev et al.,
(2000) indicated that artichoke a protective effect of $5 \%$ on humoral immune response (increase of haemagutination).

Thejass and Kuttan (2006) noticed that broccoli enhanced production of cytokines IL -2 and IFN - gamma. As for the fruits, vegetables and legumes groups best treatment was that of powdered vegetables, followed by vegetables extract, legumes extract, fruits extracts, legumes powder \& fruits powder. In case of beta globulin, the best treatment was also the vegetable powder but after that arrangement was different from that of the alpha globulin. Fruit extract group came second to vegetable powder, then fruit extract, vegetable extract, legumes powder and legumes extract.

Table.1 Effect of feeding fruits, vegetables and legumes groups powders \& extracts ) on food intake, PER, FER, and BWG \% ) of hyperglycemic rats

\begin{tabular}{|c|c|c|c|c|c|c|c|}
\hline \multirow{2}{*}{$\begin{array}{c}\text { Groups } \\
\text { Variables }\end{array}$} & \multirow{2}{*}{$\begin{array}{c}\text { Control } \\
(+\end{array}$} & \multicolumn{2}{|c|}{ Fruits } & \multicolumn{2}{|c|}{ Vegetables } & \multicolumn{2}{|c|}{ Legumes } \\
\hline & & $\begin{array}{c} \\
\text { Powder } \\
\mathbf{2 0 \%}\end{array}$ & $\begin{array}{c}\text { Extract } \\
20 \%\end{array}$ & $\begin{array}{c}\text { Powder } \\
20 \%\end{array}$ & $\begin{array}{c}\text { Extract } \\
20 \%\end{array}$ & $\begin{array}{c}\text { Powder } \\
20 \%\end{array}$ & $\begin{array}{c}\text { Extract } \\
20 \%\end{array}$ \\
\hline Food intake (g) & $17.1 \pm 0.5^{\mathrm{a}}$ & $16.1 \pm 0.3^{d}$ & $18.1 \pm 0.5^{b}$ & $25.25 \pm .12^{\mathrm{a}}$ & $15.6 \pm 0.3^{d}$ & $17.1 \pm 0.3^{c}$ & $17.7 \pm 0.5 b^{c}$ \\
\hline PER & $-.332 \pm .211^{\mathrm{ab}}$ & $.104 \pm 053^{c}$ & $.198 \pm .118^{\mathrm{abc}}$ & $.165 \pm .061^{\mathrm{abc}}$ & $.257 \pm .076^{\mathrm{abc}}$ & $.210 \pm .191^{\mathrm{abc}}$ & $.538 \pm .145^{\mathrm{a}}$ \\
\hline FER & $-.040 \pm .025^{a b}$ & $.012 \pm 06^{c}$ & $.024 \pm .014^{\mathrm{abc}}$ & $.020 \pm .007^{b c}$ & $.031 \pm .009^{\mathrm{abc}}$ & $.025 \pm .023^{\mathrm{abc}}$ & $.064 \pm .018^{a}$ \\
\hline Initial weight (g) & $149.3 \pm 10.2^{\mathrm{ab}}$ & $148 \pm 5.19^{c}$ & $150.7 \pm 6.8^{\mathrm{bc}}$ & $149.3 \pm 14.1^{b c}$ & $163.3 \pm 8.7^{\mathrm{a}}$ & $151 \pm 8.2^{\mathrm{bc}}$ & $136.3 \pm 5.7^{d}$ \\
\hline Final weight (g) & $130.3 \pm 39.6^{b}$ & $153.7 \pm .5^{\mathrm{ab}}$ & $162.7 \pm 10.1^{\mathrm{ab}}$ & $163.3 \pm 10.4^{\mathrm{ab}}$ & $176.7 \pm 12.5^{\mathrm{a}}$ & $163 \pm 3.5^{\mathrm{ab}}$ & $168.3 \pm 9.1^{\mathrm{ab}}$ \\
\hline BWG \%) & $-12.73 \pm 3.3^{\mathrm{ab}}$ & $3.85 \pm 2.08^{c}$ & $7.96 \pm 4.71^{b c}$ & $9.38 \pm 4.53^{b c}$ & $8.21 \pm 2.12^{b c}$ & $7.95 \pm 7.8^{\mathrm{bc}}$ & $23.48 \pm 6.67^{\mathrm{a}}$ \\
\hline
\end{tabular}

Mean \pm SD

*Different letters on the values mean significant differences at $\mathrm{P}<0.05$.

$* *$ Different letters on the values mean significant differences at $\mathrm{P}<0.01$. 
Table.2 Effect of feeding fruits, vegetables and legumes groups powders \& extracts ) on internal organs weight $\mathrm{g}$ ) of hyperglycemic rats

\begin{tabular}{|c|c|c|c|c|c|c|c|}
\hline \multirow{2}{*}{$\begin{array}{c}\text { Groups } \\
\text { Variables } \\
\end{array}$} & \multirow{2}{*}{$\begin{array}{c}\text { Control } \\
(+)\end{array}$} & \multicolumn{2}{|c|}{ Fruits } & \multicolumn{2}{|c|}{ Vegetables } & \multicolumn{2}{|c|}{ Legumes } \\
\hline & & $\begin{array}{c}\text { Powder } \\
20 \%\end{array}$ & $\begin{array}{c}\text { Extract } \\
20 \% \\
\end{array}$ & $\begin{array}{c}\text { Powder } \\
20 \%\end{array}$ & $\begin{array}{c}\text { Extract } \\
20 \%\end{array}$ & $\begin{array}{c}\text { Powder } \\
20 \%\end{array}$ & $\begin{array}{c}\text { Extract } \\
20 \%\end{array}$ \\
\hline Liver & $3.74 \pm .310^{\mathrm{a}}$ & $4.47 \pm .3785^{\mathrm{a}}$ & $4.13 \pm .1184^{\mathrm{a}}$ & $3.98 \pm .4849^{\mathrm{a}}$ & $3.98 \pm .525^{\mathrm{a}}$ & $4.67 \pm .252^{\mathrm{a}}$ & $4.92 \pm .589^{\mathrm{a}}$ \\
\hline Heart & $.75 \pm .185^{\mathrm{a}}$ & $.75 \pm .05^{\mathrm{a}}$ & $.793 \pm .012^{\mathrm{a}}$ & $.73 \pm .057^{\mathrm{a}}$ & $.79 \pm .083^{\mathrm{a}}$ & $.88 \pm .076^{\mathrm{a}}$ & $.813 \pm .023^{a}$ \\
\hline & $\begin{array}{l}1.3 \pm \\
.346^{\mathrm{a}}\end{array}$ & $.956 \pm .26^{\mathrm{a}}$ & $1.09 \pm .130^{\mathrm{a}}$ & $.94 \pm .196^{\mathrm{a}}$ & $1.42 \pm .45^{\mathrm{a}}$ & $1.35 \pm .132^{\mathrm{a}}$ & $1.36 \pm .152^{\mathrm{a}}$ \\
\hline Spleen & $.696 \pm .179^{a}$ & & $.583 \pm .236^{\mathrm{a}}$ & $.68 \pm .120^{\mathrm{a}}$ & $0.7 \pm 0.1^{\mathrm{a}}$ & $.98 \pm .072^{\mathrm{a}}$ & $.95 \pm .25^{\mathrm{a}}$ \\
\hline Lungs & $1.04 \pm .092^{\mathrm{a}}$ & $1.2 \pm .410^{\mathrm{a}}$ & $.89 \pm .268^{a}$ & $1.18 \pm .45^{\mathrm{a}}$ & $1.09 \pm .11$ & $1.33 \pm .37^{\mathrm{a}}$ & $1.3 \pm 0.1^{\mathrm{a}}$ \\
\hline
\end{tabular}

Mean \pm SD; *Different letters on the values mean significant differences at $\mathrm{P}<0.05$.

$* *$ Different letters on the values mean significant differences at $\mathrm{P}<0.01$.

Table.3 Effect of feeding fruits, vegetables and legumes groups powders \& extracts ) on blood glucose level $\mathrm{mg} / \mathrm{dl}$ ) of hyperglycemic rats.

\begin{tabular}{|c|c|c|c|c|c|c|c|c|}
\hline \multirow{2}{*}{$\begin{array}{l}\text { Groups } \\
\text { Variables }\end{array}$} & \multicolumn{2}{|c|}{ Control } & \multicolumn{2}{|c|}{ Fruits } & \multicolumn{2}{|c|}{ Vegetables } & \multicolumn{2}{|c|}{ Legumes } \\
\hline & $(-)$ & $(+)$ & $\begin{array}{l}\text { Powder } \\
20 \%\end{array}$ & $\begin{array}{l}\text { Extract } \\
20 \%\end{array}$ & $\begin{array}{l}\text { Powder } \\
20 \%\end{array}$ & $\begin{array}{l}\text { Extract } \\
20 \%\end{array}$ & $\begin{array}{l}\text { Powder } \\
20 \%\end{array}$ & $\begin{array}{l}\text { Extract } \\
20 \%\end{array}$ \\
\hline $\begin{array}{l}\text { Serum glucose } \\
\text { \% decrease of } \\
\text { control (+) } \\
\% \text { decrease of } \\
\text { control (-) }\end{array}$ & $\begin{array}{l}84 \pm 2^{f} \\
-43.7\end{array}$ & $\begin{array}{l}149.3 \pm \\
1.02^{\mathrm{a}} \\
--- \\
+77.7\end{array}$ & $\begin{array}{l}130.3 \pm \\
4.51^{\mathrm{c}} \\
-12.7 \\
+55.1\end{array}$ & $\begin{array}{l}105.67 \pm 4.51^{\mathrm{e}} \\
-29.2 \\
+25.8\end{array}$ & $\begin{array}{l}119 \quad \pm \\
4.58^{d} \\
-20.3 \\
+41.7\end{array}$ & $\begin{array}{l}85.66 \pm \\
4.5^{\mathrm{f}} \\
-42.6\end{array}$ & $\begin{array}{l}107.3 \quad \pm \\
4.04^{\mathrm{e}} \\
-28.1 \\
+27.7\end{array}$ & $\begin{array}{l}140.7 \pm 9.02^{b} \\
-5.8 \\
+67.5\end{array}$ \\
\hline
\end{tabular}

Mean \pm SD; *Different letters on the values mean significant differences at $\mathrm{P}<0.05$.

$* *$ Different letters on the values mean significant differences at $\mathrm{P}<0.01$. 
Table.4 Effect of feeding fruits, vegetables and legumes groups powders \& extracts ) on fasting serum lipids profile of hyperglycemic rats.

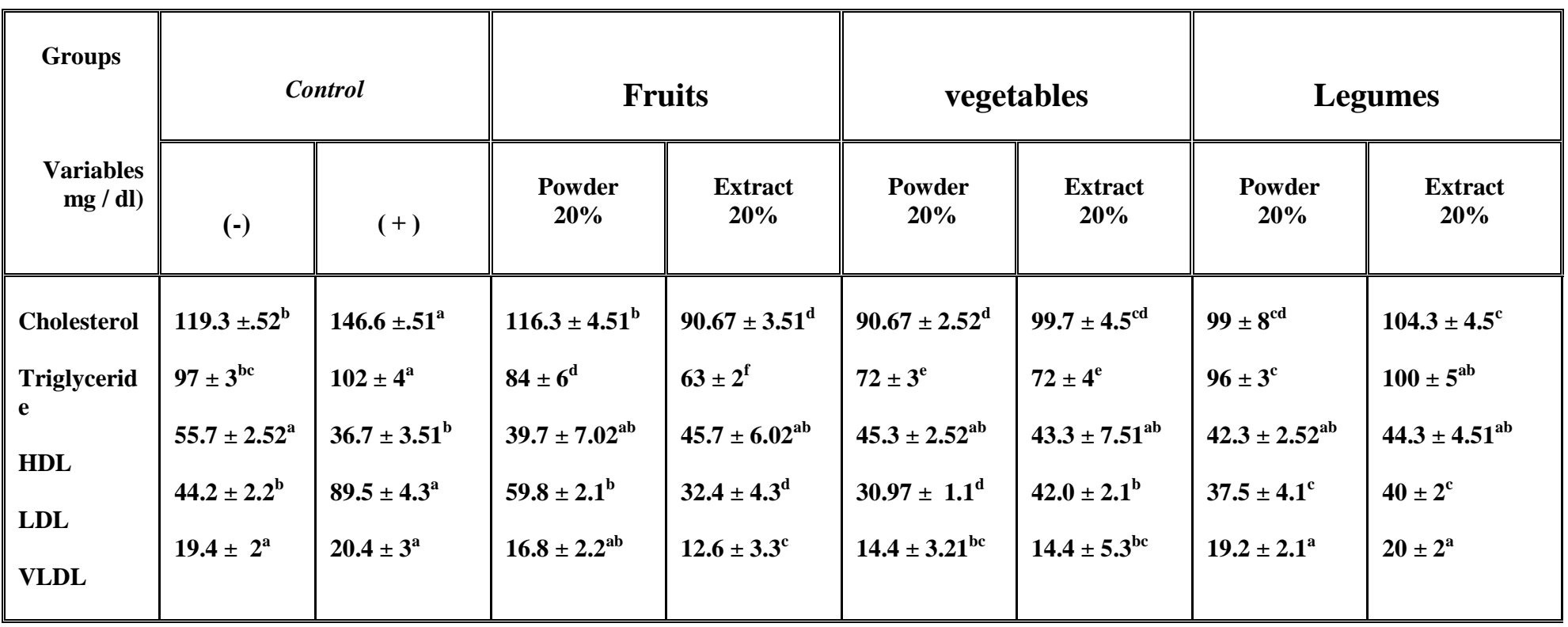

Mean \pm SD; *Different letters on the values mean significant differences at $\mathrm{P}<0.05$.

$* *$ Different letters on the values mean significant differences at $\mathrm{P}<0.01$.

Table.5 Effect of feeding fruits, vegetables and legumes groups powders \& extracts ) on liver function of hyperglycemic rats.

\begin{tabular}{|c|c|c|c|c|c|c|c|c|}
\hline \multirow{2}{*}{$\begin{array}{l}\text { Groups } \\
\text { Variables } \\
\text { U / L ) }\end{array}$} & \multicolumn{2}{|c|}{ Control } & \multicolumn{2}{|c|}{ Fruits } & \multicolumn{2}{|c|}{ Vegetables } & \multicolumn{2}{|c|}{ Legumes } \\
\hline & $(-)$ & $(+)$ & $\begin{array}{c}\text { Powder } \\
20 \%\end{array}$ & $\begin{array}{c}\text { Extract } \\
20 \%\end{array}$ & $\begin{array}{c}\text { Powder } \\
20 \%\end{array}$ & $\begin{array}{c}\text { Extract } \\
20 \%\end{array}$ & $\begin{array}{c}\text { Powder } \\
20 \%\end{array}$ & $\begin{array}{c}\text { Extract } \\
20 \%\end{array}$ \\
\hline $\begin{array}{c}\text { Liver } \\
\text { Enzymes }\end{array}$ & & & & & & & & \\
\hline GPT & $26 \pm 2^{b c}$ & $83.3 \pm 4.51^{a}$ & $26 \pm 4^{b c}$ & $24.3 \pm 5.51^{b c}$ & $35.3 \pm 4.51^{\mathrm{b}}$ & $22.67 \pm 7.51^{c}$ & $25.3 \pm 3.51^{\mathrm{bc}}$ & $35.6 \pm 3.51^{b}$ \\
\hline GOT & $62.3 \pm 2.52^{d}$ & $150.3 \pm 2.52^{\mathrm{a}}$ & $65.3 \pm 4.51^{\mathrm{d}}$ & $73.6 \pm 3.51^{\mathrm{c}}$ & $75.3 \pm 3.51^{\mathrm{c}}$ & $57.6 \pm 3.52^{\mathrm{d}}$ & $62.33 \pm 2.5^{\mathrm{d}}$ & $109.6 \pm 7.51^{b}$ \\
\hline
\end{tabular}

Mean \pm SD; *Different letters on the values mean significant differences at $\mathrm{P}<0.05$.

$* *$ Different letters on the values mean significant differences at $\mathrm{P}<0.01$. 
Table.6 Effect of feeding fruits, vegetables and legumes groups powders \& extracts ) on kidneys function of hyperglycemic rats

\begin{tabular}{|c|c|c|c|c|c|c|c|c|}
\hline \multirow{2}{*}{$\begin{array}{c}\text { Groups } \\
\text { Variables } \\
(\mathrm{mg} / \mathrm{dl}) \\
\end{array}$} & \multicolumn{2}{|c|}{ Control( + ) } & \multicolumn{2}{|c|}{ Fruits } & \multicolumn{2}{|c|}{ Vegetables } & \multicolumn{2}{|c|}{ Legumes } \\
\hline & $(-)$ & $(+)$ & $\begin{array}{c}\text { Powder } \\
20 \%\end{array}$ & $\begin{array}{c}\text { Extract } \\
20 \%\end{array}$ & $\begin{array}{c}\text { Powder } \\
20 \%\end{array}$ & $\begin{array}{c}\text { Extract } \\
20 \%\end{array}$ & $\begin{array}{c}\text { Powder } \\
20 \%\end{array}$ & $\begin{array}{c}\text { Extract } \\
20 \%\end{array}$ \\
\hline Creatinine & $.82 \pm .03^{\mathrm{bc}}$ & $1.5 \pm 0.4^{\mathrm{a}}$ & $1.33 \pm .251^{\mathrm{ab}}$ & $.84 \pm .035^{\text {bc }}$ & $.78 \pm .035^{\mathrm{c}}$ & $.92 \pm .025^{\mathrm{bc}}$ & $.96 \pm .03^{\mathrm{bc}}$ & $.85 \pm .045^{\mathrm{bc}}$ \\
\hline Urea & $26 \pm 4^{\mathrm{d}}$ & $50 \pm 3^{\mathrm{a}}$ & $44.67 \pm 5.50^{b}$ & $26 \pm 3^{d}$ & $28.67 \pm 4.51^{\mathrm{cd}}$ & $29.67 \pm 2.51^{\mathrm{c}}$ & $28.3 \pm 4.5^{\mathrm{cd}}$ & $31.67 \pm 2.52^{\mathrm{c}}$ \\
\hline Uric acid & $2.23 \pm 25^{\mathrm{ab}}$ & $2.77 \pm .075^{\mathrm{a}}$ & $2.28 \pm .03^{\mathrm{ab}}$ & $1.92 \pm .025^{\mathrm{b}}$ & $2.67 \pm .45^{\mathrm{a}}$ & $1.33 \pm .252^{\mathrm{c}}$ & $2.17 \pm .025^{\mathrm{ab}}$ & $2.53 \pm .152^{\mathrm{ab}}$ \\
\hline
\end{tabular}

Mean \pm SD; *Different letters on the values mean significant differences at $\mathrm{P}<0.05$.

**Different letters on the values mean significant differences at $\mathrm{P}<0.01$.

Table.7 Effect of feeding herbs groups powders \& extracts ) on cellular immunity phagocytes \& lymphocytes ) of hyperglycemic rats

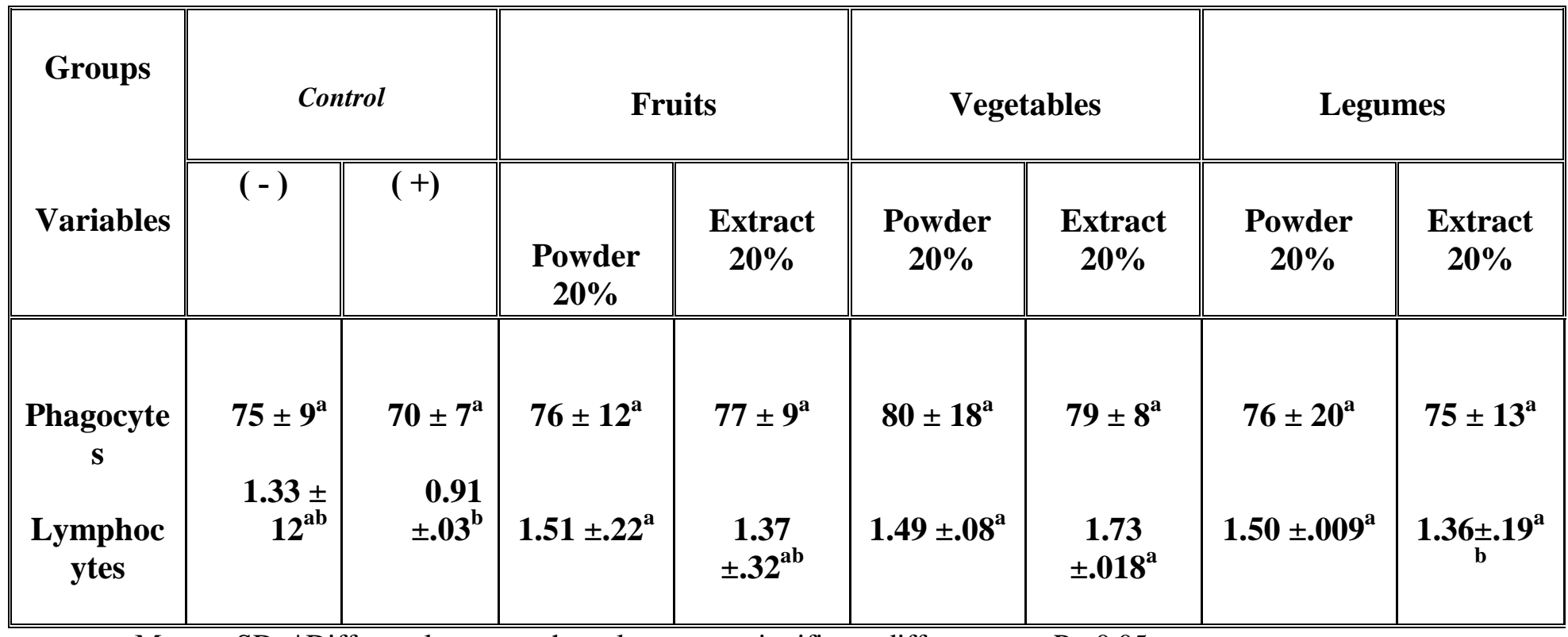

Mean \pm SD; *Different letters on the values mean significant differences at $\mathrm{P}<0.05$.

$* *$ Different letters on the values mean significant differences at $\mathrm{P}<0.01$. 
Table.8 Effect of feeding herbs groups (powders \& extracts) on cellular immunity (phagocytes \& lymphocytes ) of hyperglycemic rats (\% increase of control +)

\begin{tabular}{|c|c|c|c|c|c|c|c|}
\hline \multirow{2}{*}{$\begin{array}{l}\text { Groups } \\
\text { Variables }\end{array}$} & \multirow{2}{*}{$\begin{array}{c}\text { Control } \\
(+)\end{array}$} & \multicolumn{2}{|c|}{ Fruits } & \multicolumn{2}{|c|}{ Vegetables } & \multicolumn{2}{|c|}{ Legumes } \\
\hline & & $\begin{array}{l}\text { Powder } \\
20 \%\end{array}$ & $\begin{array}{l}\text { Extract } \\
20 \%\end{array}$ & $\begin{array}{l}\text { Powder } \\
20 \%\end{array}$ & $\begin{array}{c}\text { Extract } \\
20 \%\end{array}$ & $\begin{array}{l}\text { Powder } \\
20 \%\end{array}$ & $\begin{array}{c}\text { Extract } \\
20 \%\end{array}$ \\
\hline $\begin{array}{r}\% \text { Phagocytes of } \\
\text { control }(+)\end{array}$ & ----- & +8.57 & +10.00 & +14.29 & +12.86 & +8.57 & +7.14 \\
\hline $\begin{array}{c}\text { \% Lymphocytes of } \\
\text { control (+) }\end{array}$ & --- & +65.93 & +50.55 & +63.74 & $90.11+$ & $64.84+$ & +49.45 \\
\hline
\end{tabular}

$\%$ of control " +" ). Mean \pm SD

Table.9 Effect of feeding fruits, vegetables and legumes groups powders \& extracts ) on humoral immunity of hyperglycemic rats (Globulins fractions )

\begin{tabular}{|c|c|c|c|c|c|c|c|c|}
\hline \multirow{2}{*}{$\begin{array}{c}\text { Groups } \\
\text { Variables } \\
\text { g/dl ) } \\
\end{array}$} & \multicolumn{2}{|c|}{$\begin{array}{c}\text { Control } \\
(+)\end{array}$} & \multicolumn{2}{|c|}{ Fruits } & \multicolumn{2}{|c|}{ Vegetables } & \multicolumn{2}{|c|}{ Legumes } \\
\hline & $(-)$ & $(+)$ & $\begin{array}{c}\text { Powder } \\
20 \%\end{array}$ & $\begin{array}{c}\text { Extract } \\
20 \%\end{array}$ & $\begin{array}{c}\text { Powder } \\
20 \%\end{array}$ & $\begin{array}{c}\text { Extract } \\
20 \%\end{array}$ & $\begin{array}{c}\text { Powder } \\
20 \%\end{array}$ & $\begin{array}{c}\text { Extract } \\
20 \%\end{array}$ \\
\hline $\begin{array}{r}\text { Globulins } \\
\text { Alpha }\end{array}$ & $\begin{array}{l}1.27 \\
\pm .014^{\mathrm{ab}}\end{array}$ & $\begin{array}{l}1.15 \pm \\
.027^{\mathrm{abc}}\end{array}$ & $\begin{array}{l}1.02 \\
\pm .009^{c}\end{array}$ & $\begin{array}{l}1.19 \pm \\
0.1^{\mathrm{abc}}\end{array}$ & $1.33 \pm .08^{\mathrm{a}}$ & $\begin{array}{l}1.26 \\
\pm .13^{\mathrm{ab}}\end{array}$ & $\begin{array}{l}1.09 \pm \\
0.07^{\mathrm{bc}}\end{array}$ & $\begin{array}{l}1.25 \pm \\
0.1^{\mathrm{ab}}\end{array}$ \\
\hline Beta & $\begin{array}{l}1.41 \pm \\
0.1^{\mathrm{a}}\end{array}$ & $1.21 \pm 0.1^{\mathrm{ab}}$ & $\begin{array}{l}1.33 \\
\pm .12^{\mathrm{ab}}\end{array}$ & $1.29 \pm .1^{\mathrm{ab}}$ & $\begin{array}{l}1.34 \\
\pm .07^{\mathrm{ab}}\end{array}$ & $\begin{array}{l}1.23 \\
\pm .08^{\mathrm{ab}}\end{array}$ & $\begin{array}{l}1.16 \\
\pm .13^{\mathrm{ab}}\end{array}$ & $1.09 \pm .04^{\mathrm{b}}$ \\
\hline Gamma & $\begin{array}{l}1.85 \\
\pm .04^{\mathrm{d}}\end{array}$ & $1.67 \pm .11^{\mathrm{e}}$ & $2.02 \pm .06^{\mathrm{c}}$ & $1.95 \pm .04^{\mathrm{c}}$ & $2.41 \pm 0.1^{\mathrm{a}}$ & $2.18 \pm .07^{\mathrm{b}}$ & $1.84 \pm .05^{\mathrm{d}}$ & $\begin{array}{l}1.75 \\
\pm .09^{\mathrm{de}}\end{array}$ \\
\hline
\end{tabular}

$$
\text { Mean } \pm \text { SD }
$$

*Different letters on the values mean significant differences at $\mathrm{P}<0.05$.

$* *$ Different letters on the values mean significant differences at $\mathrm{P}<0.01$. 
Table.10 Effect of feeding fruits, vegetables and legumes groups powders \& extracts ) on humoral immunity of hyperglycemic rats (Globulins fractions ) \% increase of control $(+)$

\begin{tabular}{|c|c|c|c|c|c|c|c|}
\hline \multirow{2}{*}{$\begin{array}{l}\text { Groups } \\
\text { Variables }\end{array}$} & \multirow{2}{*}{$\begin{array}{c}\text { Control } \\
(+)\end{array}$} & \multicolumn{2}{|c|}{ Fruits } & \multicolumn{2}{|c|}{ Vegetables } & \multicolumn{2}{|c|}{ Legumes } \\
\hline & & $\begin{array}{c}\text { Powder } \\
20 \%\end{array}$ & $\begin{array}{c}\text { Extract } \\
20 \%\end{array}$ & $\begin{array}{c}\text { Powder } \\
20 \%\end{array}$ & $\begin{array}{c}\text { Extract } \\
20 \%\end{array}$ & $\begin{array}{c}\text { Powder } \\
20 \%\end{array}$ & $\begin{array}{c}\text { Extract } \\
20 \%\end{array}$ \\
\hline $\begin{array}{c}\text { GLOBULINS: } \\
\text { \% ALPHA of } \\
\text { control (+) }\end{array}$ & ---- & -11.30 & +3.48 & +15.65 & +9.57 & -5.22 & +8.70 \\
\hline $\begin{array}{l}\% \text { BETA of } \\
\text { control }(+)\end{array}$ & ---- & +9.92 & +6.61 & +10.74 & +1.65 & -4.13 & -9.92 \\
\hline $\begin{array}{c}\text { \% GAMMA of } \\
\text { control (+) }\end{array}$ & ---- & +20.96 & +16.77 & +44.31 & +30.54 & +10.18 & +4.79 \\
\hline
\end{tabular}

$\%$ of control " + " );Mean \pm SD

*Different letters on the values mean significant differences at $\mathrm{P}<0.05$.

**Different letters on the values mean significant differences at $\mathrm{P}<0.01$.

Table.11 Effect of feeding fruits, vegetables and legumes groups (powders\& extracts ) on some humoral immunity indices of hyperglycemic rats (total protein " TP ", albumin "ALB", total globulin "GLOB" and A/B ratio)

\begin{tabular}{|c|c|c|c|c|c|c|c|c|}
\hline \multirow{2}{*}{$\begin{array}{l}\text { Groups } \\
\text { Variables }\end{array}$} & \multicolumn{2}{|c|}{ Control } & \multicolumn{2}{|c|}{ Fruits } & \multicolumn{2}{|c|}{ Vegetables } & \multicolumn{2}{|c|}{ Legumes } \\
\hline & $\begin{array}{c}\text { Control } \\
(-)\end{array}$ & $\begin{array}{c}\text { Control } \\
(+) \\
\end{array}$ & $\begin{array}{l}\text { Powder } \\
20 \%\end{array}$ & $\begin{array}{c}\text { Extract } \\
20 \%\end{array}$ & $\begin{array}{c}\text { Powder } \\
20 \%\end{array}$ & $\begin{array}{c}\text { Extract } \\
20 \%\end{array}$ & $\begin{array}{c}\text { Powder } \\
20 \%\end{array}$ & $\begin{array}{c}\text { Extract } \\
20 \%\end{array}$ \\
\hline TP g / dl ) & $6.58 \pm .017^{\mathrm{c}}$ & $6.05 \pm .07^{\mathrm{c}}$ & $6.70 \pm .007^{\mathrm{c}}$ & $6.79 \pm .12^{c}$ & $7.95 \pm .15^{\mathrm{a}}$ & $6.98 \pm .01^{\mathrm{b}}$ & $6.5 \pm 0.3^{c}$ & $6.48 \pm .09^{c}$ \\
\hline ALB g / dl ) & $2.32 \pm .09^{\mathrm{a}}$ & $2.02 \pm .004^{\mathrm{b}}$ & $2.33 \pm .08^{\mathrm{a}}$ & $2.36 \pm .08^{\mathrm{a}}$ & $2.36 \pm .15^{\mathrm{a}}$ & $2.31 \pm 0.1^{\mathrm{a}}$ & $2.41 \pm 0.1^{\mathrm{a}}$ & $2.39 \pm .08^{\mathrm{a}}$ \\
\hline GLOB g / dl) & $\begin{array}{r}4.53 \pm \\
.009^{\mathrm{e}}\end{array}$ & $4.03 \pm .014^{\mathrm{d}}$ & $4.54 \pm .011^{\mathrm{cd}}$ & $4.43 \pm 0.06^{\mathrm{c}}$ & $5.08 \pm .03^{\mathrm{a}}$ & $4.67 \pm .04^{\mathrm{b}}$ & $4.09 \pm .02^{\mathrm{f}}$ & $4.09 \pm .07^{\mathrm{f}}$ \\
\hline A / B g / dl ) & 0.512 & 0.501 & 0.533 & 0.533 & 0.465 & 0.495 & 0.589 & 0.584 \\
\hline
\end{tabular}

Mean \pm SD; *Different letters on the values mean significant differences at $\mathrm{P}<0.05$.

$* *$ Different letters on the values mean significant differences at $\mathrm{P}<0.01$.

A / B: Albumin to globulin ratio. 
Table.12 Effect of feeding fruits, vegetables and legumes groups powders \& extracts ) on some humoral immunity indices of hyperglycemic rats total protein " TP ", albumin " ALB ", total globulin " GLOB " and A/B ratio) $\%$ increase of control $(+)$

\begin{tabular}{|c|c|c|c|c|c|c|c|c|}
\hline \multirow{2}{*}{$\begin{array}{l}\text { Groups } \\
\text { Variables }\end{array}$} & \multicolumn{2}{|c|}{ Control } & \multicolumn{2}{|c|}{ Fruits } & \multicolumn{2}{|c|}{ vegetables } & \multicolumn{2}{|c|}{ Legumes } \\
\hline & $\begin{array}{c}\text { Control } \\
(-)\end{array}$ & $\begin{array}{c}\text { Control } \\
(+) \\
\end{array}$ & $\begin{array}{c}\text { Powder } \\
20 \% \\
\end{array}$ & $\begin{array}{c}\text { Extract } \\
20 \%\end{array}$ & $\begin{array}{c}\text { Powder } \\
20 \%\end{array}$ & $\begin{array}{c}\text { Extract } \\
20 \%\end{array}$ & $\begin{array}{c}\text { Powder } \\
20 \%\end{array}$ & $\begin{array}{c}\text { Extract } \\
20 \%\end{array}$ \\
\hline $\mathbf{T P}(\mathrm{g} / \mathrm{dl})$ & +13.2 & --- & +10.74 & +12.23 & +31.41 & +15.37 & +7.44 & +7.11 \\
\hline $\operatorname{ALB}(\mathrm{g} / \mathrm{dl})$ & +14.9 & --- & +15.35 & +16.83 & +16.83 & +14.36 & +19.31 & +18.32 \\
\hline$\underset{\text { dl) }}{\operatorname{GLOB}(\mathrm{g} /}$ & +12.4 & --.- & +12.66 & +9.93 & +26.06 & +15.88 & +1.49 & +1.49 \\
\hline $\mathrm{A} / \mathrm{B} \mathrm{g} / \mathrm{dl})$ & +2.19 & ---- & +6.39 & +6.39 & -7.19 & -1.20 & +17.57 & +16.57 \\
\hline
\end{tabular}

*Different letters on the values mean significant differences at $\mathrm{P}<0.05$.

** Different letters on the values mean significant differences at $\mathrm{P}<0.01$.

A / B: Albumin to globulin ratio.

Arrangement in case of gamma globulin was more or less similar to thus of alpha globulin as vegetables powder, was the best treatment, followed by vegetables extract, fruit powder, fruit extract, legumes powder $\&$ legumes extract. Last two groups showed also lease values considering alpha globulin.

Serum total protein (TP), albumin (ALB), globulin (Glob) and albumin / globulin ratio (A / B)

\section{Total protein (TP)}

It is evident (Tables 11) that due to hyperglycemia, TP was decreased; difference however was insignificant. On the contrary TP increased when feeding rats diets with added botanical materials. For fruits, vegetables and legumes diet, vegetable powder treatment showed highest
TP, followed by vegetable extract, fruits extract, fruits powder, legumes powder and legumes extract diet. Overall, the best treatment was recorded for vegetable powder, vegetable extract, fruits extract, fruits powder, legumes powder and legumes extract. Although legumes extract showed the lowest correction, improvement of TP was by $7.44 \%$

\section{Albumin (ALB)}

ALB decreased by hyperglycemia and increased by different treatments. ALB of fruits, vegetables \& legumes groups was highest for legumes powder, followed by legumes extract, fruits extract, vegetables powder, fruits powder and vegetables extract. With some exceptions arrangement of groups was nearly revealed compared to that of the TP. 


\section{Serum globulin (GLOB)}

Total globulins (Tables 11) declined by hyperglycemia and improved by different feeding treatments, following nearly the same arrangement as that of gamma globulin (Tables 11). Highest improvement of $T$. globulins in fruits, vegetables and legumes groups for vegetables powder treatment, followed by vegetables extract, fruits powder, fruits extract, legumes powder \& legumes extract.

\section{A / B ratio}

A / B ratio did not show the arrangement recorded for $\mathrm{TP}$, ALB, or $\mathrm{T}$. globulins (GLOB). Anyhow, A / B ratio decreased by hyperglycemia, while was increased when feeding diabetic rats on tested plants. For fruits/ vegetables/ legumes treatments the best group was recorded for legumes powder one, followed by legumes extract, fruits powder, fruits extract, vegetables extract \& vegetables powder. Considering all tested plants the best treatment was that of legumes powder followed by legumes extract, fruits powder, fruits extract, vegetables extract, and vegetables powder. The last treatment caused a decreased in A / B ratio by $7.19 \%$, while best group (legumes powder) showed $16.57 \%$ improvement (increase).

\section{References}

Abdullah, T.H., Kirkpatrick, D.V. and Carter, J. 1989. Enhancement of natural killer cell activity in AIDS with garlic. Dtsch. Z. Onkol., 21: 52.

Abo-Shadie, A.Y. 2002 . Study of Effect of Some Plants Which Contain Sulphur on Diabetic Rats. M. Sc. Thesis, Faculty of Home Economics, Minufiya University.

Ahmed, Reham, R.A.S. 2007. Therapeutic Effects of Leaves Obtained From
Some Common Trees in Egypt on the Experimental Rats. M. Sc. Thesis, Faculty of Home Economics, Minufiya University.

Ali, M., Thomson, M., Bordia, T. and AlQattan, K.K. 2006. Including garlic in the diet may help lower blood glucose, cholesterol, and triglycerides. J. Nutr., 136(3): 800S-802S.

American Diabetes Association (ADA) 2010. Diagnosis and classification of diabetes mellitus. Diabetes Care, 33: S62-9.

American Diabetes Association. 2014. Standards of medical care for diabetes Diabetes Care, 37 Supplement.

Arola, L., Pinent, M., Blay, M., Blade, M.C., Salvado, M.J. and Ardevol, A. 2004. Grape seed-derived procyanidins have an antihyperglycemic effect in streptozotocin-induced diabetic rats and insulinomimetic activity in insulin-sensitive cell lines. $J$. Endocrinol., 145(11): 4985-4990.

Boyum, A. 1968. Isolation of mononuclear cells \& granulocytes from human blood. Scand. J. Clin. Lab. Invest., 21: 77.

Burrels, S. and Wells, P.W. 1977. In-vitro stimulation of ovine lymphocytes. Res. Vet. Sci., 23: 84-86.

Carawy, W. 1955. Uric acid colorimetric method. Am. J. Clin. Path., 25: 840.

Chapman, D.G., Castilla, R. and Campbell, J.A. 1959. Evaluation of protein in food I: A method for the determination of protein efficiency ratio. Can. J. Biochem. Physiol., 37: $679-686$.

Choi, S.W., Benzie, I.F., Ma, S.W., Strain, J.J., and Hannigan, B.M. 2008. Acute hyperglycemia and oxidative stress: Direct cause and effect? Free Radic. Biol. Med., 44: 1217-31.

Contarow, S.E., Schepartz, A. 1967. Biochemistry. Fourth Edition, W. B. Saunders Company, Philadelphia \& 
London, page. 443.

Cravotto, G., Boffa, L., Genzini, L., and Garella, D. 2010. Phytotherapeutics: An evaluation of the potential of 1000 plants. J. Clin. Pharm. Ther., 35: 1148.

Denise, I., Bounous, A., Raymond, Q., Compagnoli, A. and John Brown, B. 1992. Comprison of MTT colorimetric assay \& tritiated thymidiue uptake for lymphocyte proliferation assay using chicken splenlocytes. Avian Dis., 36: 1022-1027.

Desai, A. and Bhide, M. 1985. Hypoglycemic effect of Hanitonia suavcolens. Indian. J. Med., 81: 86-91.

Drury, R. A. and Wallington, E.A. 1980. Carlton,s Histological Technique. $5^{\text {th }}$ Ed. Oxford Univ.

Eidi, A., Eidi, M. and Esmaeili, E. 2006. Antidiabetic effect of garlic (Allium sativum L.) in normal and streptozotocin-induced diabetic rats. $J$. Phytomed., 13(9-10): 624-629.

El-Adawi, A.S. 1997. Effect of Fiber on Level of Blood Glucose. Ph. D Thesis, Faculty of Home Economics. Minufiya University.

El-Malah, Maysa, M. Sh. 2007. Study The Effect of Broccoli on Both Hypercholesterolemic and Hyperglycemic Rats. Ph. D. Thesis, Faculty of Home Economics, Helwan University.

El-Sayed, H.H. 2001. Biological Studies on the Effect of Portulaca oleracea, L. on Lowering Lipids and Blood Sugar in Experimental Animals. Ph. D Thesis, Faculty of Home Economics. Minufiya University.

El-Sayed, Mona, A.A. 2005. Effect of Some Seeds on Hypercholesterolemic Rats, Ph.D. Thesis, Faculty of Specific Education, Ain Shams University.

Fatani, A.J., Ahmed, A.A. and El-Alfy, A.T. 2005. Protective effect of red grape seeds proanthocyanidins against induction of diabetes by alloxan in rats. J. Pharmacol. Res., 52(3): 264270.

Fawcette, J.K. and Scott, J.E. 1960. A rapid and precise method for the determination of blood urea. J. Clin. Pathol., 13: 156-159.

Fnedewaid, W.T. 1972. Determination of HDL. Clin. Chem., 18: 499.

Gadall, Sanna, M.M. 2007. Effect of Temph as a Fermented Food Produced from Some Legumes on Hypercholesterolemic Rats. Ph. D.Thesis, Faculty of Specific Education, Ain Shams University.

Ghamry, Heba, I. 2004. Effect of the Different Processing of Fenugreek Seeds on Blood Glucose Level in Rats. M. SC. Thesis, Faculty of Home Economies, Minufiya Univ.

Giacco, R., Clenent, G. and Riccardi, G. 2002. Dietary fiber in treatment of diabetes. Dig. Liver. Dis., 34(2) Suppl. S140 - S144.

Gordon, T. and Amer, M. 1977. Determination of HDL. J. Med., 62: 707.

Henry, D.S. 1974. Clinical Chemist: Principles and technics, $2^{\text {nd }}$ Edition, Hagerstown MD, Harcer, Row, P. 882.

Hudson, L. and Hay, F.C. 1980. Immunology. $2^{\text {nd }}$ ed. Black-Well Scientific Publication.Oxford, London, Edinburgh, Boston, Melbourve.

Jacobs, N.J. and Van Denmark, P.J. 1960. Determination of triglycerides. Arch. Biochem. Biophys., 88: 250-255.

Kim, H.Y., Yokozawa, T., Cho, E.J., Choi, J.S. and Chung, H.Y. 2002. Antioxidant effects of isorhamnetin 3,7-di-O-beta-D-glucopyranoside isolated from mustard leaf (Brassica juncea) in rats with streptozotocininduced diabetes. J. Agric. Food Chem., 50(19): 5490-5495. 
Laemmli, U.K. 1970. Structural proteins during the assembly of the head of bacteriophage T4. Nature, 227(15): 680-685.

Larsen, K. 1972. Creatinine coloremitric kinetic method. J. Clin. Chem., 41: 209.

Lee, R.D. and Nieman, D.C. 1996. Nutritional Assessment. $2^{\text {nd }}$ Ed. Mosby, Missoun, USA.

Lee, R.D. and Nieman, D.C. 2003. Nutritional Assessment. $3^{\text {rd }}$. Pub, by Mc. Graw-Hill. Avenue of the Americans, New York. s287.

Matos, C.I., Zuidmeer, L., Salentijn, E., Rivas, M.F., Mancebo, E.G., Asero, R., Pelgrom, K.T., Gilissen, LJ. and Ree, R. 2006. The role of profiling and lipid transfer protein in strawberry allergy in the Mediterranean area. $J$. Clin. Exp. Allergy, 36(5): 666-675.

McDougall, G.J., Kulkarni, N.N. and Stewart, D. 2008. Current developments on the inhibitory effects of berry polyphenols on digestive enzymes. Biofactors, 34: 73-80.

Mohamed, Manal, A. 2006. The Effect of Some Nuts on Hyperglycemic and hypercholesterolemic rats. M. Sc. Thesis, Faculty of Home Economics, Helwan University.

Nada, S.A., Bashandy, S.A.E. and Negm. S.A. 1997. Evaluation of the hypoglycemic activity of a traditional herbal preparation in male diabetic rats. Fitoterapia, 68(3): 240-244.

Nation Diabetes Data Group (NDDG) 1994. Classification and diagnosis of diabetes mellitus and other categories of glucose intolerance. Diabetes, 28: $1039-1057$.

Park, S.J., Shin, W.H., Seo, J.W., Kim E.J. 2007. Anthocyanins inhibit airway inflammation and hyperresponsiveness in a murine asthma model. Food Chem. Toxicol., 45:
1459-67.

Rai-El-Balahaa, G., Pellerin, J.L., Bodin, G., Abdullah, H.A. and Hiron, H. 1985. Lymphoplastic transformation assay of sheep peripheral blood lymphocytes: A new rapid and easy to read techniques. Comp. Immune. Microbiol. Infec. Dis., 8: 311-318.

Reeves, P.G., Nielson, F.H. and Fahmy, G.C. 1993. Reports of the American Institute of Nutrition, adhoc willing committee on reformulation of the AIN 93, Rodent diet. J. Nutri., 123: 1939-1951.

Ronald, R. 2001. Vegetables, Fruits and Herbs in Herbs Promation. $1^{\text {st }}$. Pub, by CRC press LLC. Boca Raton, Washington, D.C. 210-212.

Saad, Gehan, G.A.A. 2006. Biological Study The Probable Medical Action of Some Common and Uncommon Botanical Parts in Man's Diet. M. Sc. Thesis, Faculty of Home Economics, Minufiya Univ.

Sauls, D.L. Banini, A.E., Boyd, L.C., Allen, J.C., Allen, H.G. 2006. Muscadine grape products intake, diet and blood constituents of non-diabetic and type 2 diabetic subjects. J. Nutri., 22(11-12): 1137-1145.

SPSS. 1998. Statistical Package for Social Science, Computer Software, Ver.10, SPSS Company, London, UK.

Stoev, S.D., Anguelov, G., Ivanov, I. and Pavlov, D. 2000. Influence of ochratoxin A and an extract of artichoke on the vaccinal immunity and health in broiler chicks. J. Exp. Toxicol. Pathol., 52(1): 43-55.

Thejass, P. and Kuttan, G. 2006. Augmentation of natural killer cell and antibody-dependent cellular cytotoxicity in BALB/c mice by sulforaphane, a naturally occurring isothiocyanate from broccoli through enhanced production of cytokines IL-2 
and IFN-gamma. $J$. Immunopharmacol. Immunotoxicol., 28(3): 443-457.

Thiery, J., Rassoul, F., Salvetter, J., Reissig, D., Schneider, W. and Richter, V. 2006. The influence of garlic (Allium sativum) extract on interleukin 1alphainduced expression of endothelial intercellular adhesion molecule- 1 and vascular cell adhesion molecule-1. $J$. Phytomed., 13(4): 230-235.

Tietz, N.W. 1976. Fundamentals of Clinical Chemistry. Philade Iphia, W.B. Saunders, P 243.

Tyler, V. 1994. Herbs of Choice: The Therapeutic Use of Phytomedicinals. Pharmaceutical Products Press, New York.

Valentova, K., Ulrichova, J., Cvak, L., and Simanek, V. 2006. Cytoprotective effect of a bilberry extract against oxidative damage of rat hepatocytes. Food Chem., 101: 912-7.

Velasquez, M.T., Abraham, A.A., Kimmel, P.L., Farkas, T., Zallasi S. and Michaelis, O.E. 1995. Diabetic glomerulopathy in the Shrin. Corpulent rat Diabetologia, 38: 31-38.
Watson. 2012. Impact of Mulberry Leaf on Type 2 Diabetes: A review of herbal immunomodulators. J. Altern. Med. Rev., 11(2): 128-150.

Weichselbaum, T.E. 1946. An accurate and rapid method for determination of proteins in small amounts of blood serum and plasma. Am. J. Clin. Path., 16: 40.

WHO. 1980. Expert committee on Diabetes Mellitus, second report. Technical report series 646 World Health organization, Geneva.

Winlers, N., Spelman, K., Burns, J., Nichols, D., Ottersberg, S. and Tenborg, M. 2006. Modulation of cytokine expression by traditional medicines: A review of herbal immunomodulators. J. Altern. Med. Rev., 11(2): 128-150.

Woldehiwet, Z. and Rowan, T.G. 1990. Some observations on the effects of age of calves on the phagocytosis and killing of Staphylococcus aureus by polymorphonuclear leucocytes. $\mathrm{Br}$. Vet. J., 146: 165.

Yound, D.S. 1975. Determination of GoT. Clin. Chem., 21: 1.

\section{How to cite this article:}

Hala Mohamed Ali Wahba. 2016. Effect of Some Fruits, Vegetables and Legumes on the Immunity of Diabetic Rats. Int.J.Curr.Microbiol.App.Sci. 5(10): 185-203. doi: http://dx.doi.org/10.20546/ijcmas.2016.510.021 